\title{
POVEZANOST FENOMENA AFANTAZIJA SA PREFERENCIJOM KA ODREĐENIM FILMSKIM ŽANROVIMA ${ }^{2}$
}

\begin{abstract}
Abstrakt
Afantazija je nedavno identifikovan fenomen koji se definiše kao nemogućnost stvaranja mentalnih slika. Cilj ovog istraživanja bio je da se ispita da li se na osnovu preferencije filmskog žanra može predvideti nivo sposobnosti zamišljanja mentalnih slika ispitanika, te da se ispita postoje li statistički značajne razlike između ispitanika koji preferiraju različite filmske žanrove u pogledu afantazije. Uzorak je sačinjavalo 925 ispitanika (muškarci, $n=187$; žene, $n=738)$. Starost ispitanika kretala se od 18 do 85 godina $(M=$ 31.13; $S D=10.93)$. Afantazija je operacionalizovana preko skora na instrumentu VVIQ (Vividness of Visual Imagery Questionnaire), a korišćen je i Instrument za merenje omiljenih filmskih žanrova napravljen za svrhe ovog istraživanja. Pouzdanosti na skalama afantazija otvorenih $(\alpha=.874)$ i zatvorenih očiju $(\alpha=.936)$ pokazuju visoku pouzdanost interne konzistencije. Rezultati pokazuju da fenomen afantazije ne može da se predvidi na osnovu preferencija filmskih žanrova $\left(F(6,918)=0.91, \mathrm{p}=.489, R^{2}=.006\right)$, kao i da ne postoje statistički značajne razlike u afantaziji između ispitanika koji preferiraju različite filmske žanrove $(F(5 / 919)=.16, p=.976)$. Metodom multiple linearne regresije suprotnog smera, dobijeno je da statistički značajno afantazija može da predvidi jedino preferencije žanra Komedija $(F(2,922)=4.67, p=.010)$ sa $R^{2}=.010(\beta=-.12 ; p=.003)$. Kako su postupkom multiple regresione analize suprotnog smera dobijeni različiti rezultati, na osnovu afantazije možemo do određene mere predvideti preferencije filmskih žanrova, što se eventualno može objasniti rezultatima prethodnih istraživanja koja su govorila o tome da je afantazija urođena.
\end{abstract}

Ključne reči: afantazija - otvorene oči, afantazija - zatvorene oči, mentalne slike, filmski žanrovi, VVIQ

\section{Uvod}

„Kada neko zatraži da zamislimo poznati predmet ili da se prisetimo skorašnjeg događaja, većina ljudi se može setiti slika koje su manje živopisne od originala,

\footnotetext{
${ }^{1}$ anjaa.stojkovic@gmail.com

${ }^{2}$ Rad je prezentovan na međunarodnoj konferenciji Days of Applied Psychology (25. i 26. septembra, 2020; Filozofski fakultet u Nišu, Srbija).
} 
ali imaju „vizuelni osećaj“. Ovo izražava našu sposobnost da doživimo vizuelne mentalne slike“ (Zeman et al., 2010, pp. 145). Fantazija je grčka reč za imaginaciju, za koju Aristotel govori da je „sposobnost/moć pomoću koje nam je fantazam (slika ili mentalna reprezentacija) predstavljen" (Aristotle, trans. 1986). Na osnovu ovoga, Zeman i saradnici (Zeman, Dewar, \& Della Sala, 2015) predlažu upotrebu termina „afantazija“ za označavanje stanja smanjene ili nepostojeće mogućnosti vizualizacije mentalnih slika.

Afantazija je ime koje se koristi za označavanje stanja koje utiče na sposobnost gledanja slika u umu, tako da ljudi sa afantazijom imaju manje sposobnosti za stvaranje ovih slika (Kendle, 2017). Pretpostavlja se da postoje razlike u simptomima među ljudima koji su pogođeni afantazijom, te razlike variraju u pogledu obima $\mathrm{i}$ težine (Kendle, 2017). „Mnogi ljudi mogu živeti sa afantazijom i nikada ne moraju otkriti da je imaju, jer simptomi nisu dovoljno značajni da ih upozore da više misle o tome“" (Kendle, 2017, p. 6). Ali pored toga, vizuelne slike mogu se javljati u podsvesti, na primer: u snovima. Pored nemogućnosti vizuelizacije, postoje i dodatni elementi koji se pojavljuju kao što su nemogućnost prisećanja muzike i nemogućnost prisećanja mirisa ili osećanja (Kendle, 2017). Takođe, postoji i „nesposobnost da se osete određena „osećanja” kao odgovor na sliku ili reč” (Kendle, 2017, p. 15). Ljudi sa afantazijom nalaze drugačije načine da zapamte i opišu njihova iskustva (Kendle, 2017).

Prva empirijska istraživanja mentalnih slika sproveo je Frensis Galton (1880), ispitujući razlike u mentalnim slikama koje se javljaju kada ljudi u sećanju pokušavaju da ponovo proizvedu ono što su već videli, i to tako što je od ljudi tražio da se sete kako je tog jutra izgledao njihov sto za vreme doručka, a zatim im postavljao određena pitanja o tome. Na osnovu ovog istraživanja zaključio je da postoje određene individualne razlike između ispitanika, ali i da određeni broj njih nije mogao da stvori mentalnu sliku (Galton, 1880). Dosadašnja istraživanja nisu dala dovoljno podataka o fenomenu afantazija. U jednom istraživanju uzorak je bio podeljen na one koji imaju visoku sposobnost živopisne vizuelizacije, i one koje odlikuje siromašna vizuelizacija, i kojima su elektrookulogramom snimani pokreti očiju tokom opažanja, zamišljanja i prisećanja (Marks, 1973b). Grupe su imale zadatak da upamte slike (Marks, 1973b). Rezultati su pokazali da su se ljudi sa većom sposobnošću živopisne vizuelizacije mnogo tačnije prisetili prethodno izlaganih slika, kao i da je u toj grupi ispitanika posebno bila izražena manja stopa pokreta očiju prilikom zamišljanja nego prilikom opažanja (Marks, 1973b). Afantazija je urođena (Zeman et al., 2015) ili stečena (nakon nekih hirurških zahvata, različitih povreda ili psiholoških problema, itd.), te se kognitivne funkcije u ovom slučaju, razvijaju drugačije (Zeman et al., 2010). Godine 2010. doktoru Adamu Zemanu, profesoru neurologije na Univerzitetu u Ekseteru javio se čovek kome je u šezdeset i petoj godini počelo da se događa nešto za njega neobično - mogao se setiti vizuelnih detalja, ali ih nije mogao videti (Zeman et al., 2010). Ispitanik je tada izvestio o gubitku dobrovoljnih i spontanih vizuelnih slika nakon koronarne agioplastike, koje je ranije posedovao (Zeman et al., 2010). Osim gubitka sposobnosti vizuelizacije, ovaj ispitanik nije imao nikakva druga kognitivna oštećenja nakon operacije (Zeman et al., 2010). Pet godina kasnije Zemanov tim objavio je istraživanje u kojem su učestovali 
ljudi, koji su nakon objavljenog istraživanja (2010) počeli da se javljaju i koji su imali slična iskustva. Tada je ova nemogućnost stvaranja mentalnih slika dobila i zvaničan naziv (Zeman et al., 2015). Oni su imali značajan ili potpuni deficit dobrovoljnih mentalnih vizuelnih slika, međutim, kod ispitanika mogle su se javiti i nevoljne mentale slike koje se mogu dogoditi tokom budnosti, u obliku bljeskova, ili tokom spavanja (Zeman et al., 2015). Za ispitanike u ovom istraživanju bilo je karakteristično da su izvestili o trajnoj nesposobnosti dobrovoljnog prizivanja vizuelnih slika tokom celog svog života (Zeman et al., 2015). Ispitanici su obično postajali svesni svog stanja u adolescenciji ili dvadesetim godinama, kada bi kroz socijalizaciju shvatili da većina ljudi, za razliku od njih, zaista vidi stvari u svom umu (kvazi vizuelna iskustva; Zeman et al., 2015).

Dosadašnja istraživanja pokazuju da je afantazija prisutna kod 2-3\% ljudi u populaciji (Kendle, 2017). Istraživanja rađena 2017. govore da afantaziju karakteriše nizak nivo senzornih vizuelnih slika, a ne nedostatak metakognicije ili nemogućnost introspekcije (Keogh \& Pearson, 2018). Pored toga, autori istraživanja o radnoj memoriji i afantaziji govore da za mnoge zadatke koji uključuju mentalne slike, postoje alternativne kognitivne strategije koje koriste ljudi sa afantazijom i koje vode podjednako uspešnom ponašanju, ali to ne podrazumeva da mentalne slike nemaju nikakvu ulogu u radnoj memoriji, jer postoje i okolnosti u kojima je veoma bitno vizuelno iskustvo (Jacobs, Schwarzkopf, \& Silvanto, 2018). Jedno od istraživanja pokazuje da veza između živosti vizuelnih slika i reaktivnosti na stres ili akutne reakcije na stres nije statistički značajna (Hasler-Winter, 2018). Ovi nalazi sugerišu da stres i vizuelne slike možda nisu toliko povezani kao što se misli, međutim, značajne razlike među polovima koje su uočene u uzorku i predložene u literaturi dovele su do dodatnih istraživačkih analiza - ove analize otkrile su značajan uticaj stresno-reaktivne grupe (visok / nizak) na vizuelne slike kod žena, tako da su osobe sa slabim stresom doživljavale živopisnije vizuelne slike i obrnuto (Hasler-Winter, 2018).

S obzirom na to da o afantaziji još uvek nema dovoljno podataka za njeno potpuno objašnjenje, u nastavku ćemo objasniti nekoliko pojmova blisko povezanih sa afantazijom u cilju boljeg shvatanja ovog pojma. Prvi od njih je vizualizacija (,Visualisation“, n.d.) - čin zamišljanja nečega (nekoga) formiranjem slika o nekome (nečemu) u svom umu. Realno gledanje predmeta i vizuelizacija istog ostvaruju potpuno iste efekte na telo (Kosslyn, Ganis, \& Thompson, 2001). Proučavajući ovaj pojam možemo uočiti da afantazija predstavlja odsustvo sposobnosti vizualizacije, odnosno odsustvo zamišljanja u slikama (mentalne slike). Takođe, možemo uočiti da je vizualizacija nemoguća kod ljudi kod kojih je registrovana afantazija, jer prisustvom afantazije potire se mogućnost vizualizacije. Warner i McNeill (1988) navode da mentalna slika predstavlja kognitivnu reprodukciju ili vizualizaciju objekta, scene ili osećaja kao da se dešavaju u fizičkoj realnosti. Mentalne slike se ne moraju uvek zasnivati na prethodno opaženim predmetima ili događajima, već se mogu proizvesti na novi način: kombinovanjem i modifikovanjem prethodno uskladištenih informacija (Kosslyn et al., 2001). Mentalne slike su trodimenzionalne, a produkovanje mentalnih slika može dovesti do aktivacije određenih neuronskih događaja koji su ekvivalentni onima koji se javljaju u trenutku viđenja objekta (Finke, 1986). 
Druga varijabla u našem istraživanju su filmovi, tačnije preferencije različitih filmskih žanrova. Iako nije tačno definisan datum stvaranja filmske industrije, za početak se uzima prva javna projekcija deset kratkih filmova braće Lumier održana u Parizu, decembra 1895. godine. (Gomery \& Pafort-Overduin, 2011). Filmovi su sada deo naše svakodnevice, o čemu govore statistički podaci dobijeni kod 2000 odraslih Britanaca. Prosečna odrasla osoba današnjice će odgledati 3639 filmova kod kuće i 31507 epizoda različitih serija tokom svog života (Anderer, 2019). Iako za sada ne postoje precizni podaci za Srbiju, nesumnjivo je da filmovi kao medij, zbog svoje globalne rasprostranjenosti i prihvaćenosti, predstavljaju značajan deo života prosečnog čoveka 21. veka.

Od najranijih dana kinematografije, u 19. veku pojam ,žanr“ (koji se već koristio još od 1770. godine za razvrstavanje umetničkih dela ili književnosti) korišćen je za organizovanje filmova prema tipu. Krajem 1960-ih koncept žanra postao je značajan deo filmske teorije (Hayward, 2006). U nastavku ćemo u kratkim crtama objasniti filmske žanrove korišćene u ovom istraživanju. Akcioni film karakteriše rešavanje sukoba nasilnim putem pri čemu se radnja obično dešava u sadašnjosti. Komedije mogu biti prikazane tako da uključuju realne životne događaje sa pojedinim likovima koji doprinose komičnosti filmske radnje svojim nespretnim ili nesvakidašnjim ponašanjem, čime izdvajaju ovaj filmski žanr od strogo realističnog filmskog žanra drama. Drama ima za cilj da realistično prikaže odnose među ljudima, ozbiljne životne probleme, situacije i iskušenja. Naučna fantastika oslikava nama nepoznat, drugačiji svet nastao kao posledica neke naučne inovacije. Glavna karakteristika horor filma je užas, i celokupna radnja i odnosi između likova se formiraju oko te ključne karakteristike. Trileri obično podrazumevaju glavnog junaka koji je u opasnosti i koji kroz radnju filma postepeno otkriva sve, na prvi pogled nejasne, karakteristike situacije i sebi i gledaocima. Glavni junak kod gledaoca najčešće budi saosećanje i empatiju zbog sitaucije u kojoj se našao i iz koje pokušava da izađe (Gilić, 2007).

Istraživanje preferencija filmskih žanrova svakako nije novost u psihološkim istraživanjima. Jedno od istraživanja bavilo se uticajem tipa ličnosti (ekstraverzija, neurotizam, psihoticizam) i kulture (američka, nemačka) na preferencije za savremene filmove i, u skladu sa teorijskim očekivanjima, nalazi su otkrili da su filmske sklonosti posredovane i psihoticizmom i ekstraverzijom kao dimenzijama ličnosti, kao i interakcijom psihoticizma i kultura (Weaver, Brosius, \& Mundorf, 1993). Rezultati jedne studije zaključuju da je identifikacija sa likovima važan faktor za objašnjenje uživanja u dugometražnim filmovima različitih žanrova (Igartua, 2010).

Različiti ljudi uživaju u različitim filmskim žanrovima. Dosadašnjim istraživanjima nije utvrđeno šta tačno prouzrokuje ove individualne razlike u preferencijama. Tema ovog istraživanja odabrana je sa ciljem provere da li u osnovi biranja različitih filmskih žanrova, barem delom, stoji mogućnost razmišljanja u mentalnim slikama, odnosno nemogućnost (afantazija) i proveravanje mogućnosti predikcije odabira određenih filmskih žanrova na osnovu nivoa zamišljanja putem mentalnih slika.

Opšta hipoteza: Na osnovu preferencije žanra se može statistički značajno predviteti afantazija.

Specifične hipoteze: 1) Na osnovu preferencije žanra Akcija se statistički značajno može predvideti afantazija; 2) Na osnovu preferencije žanra Komedija se sta- 
tistički značajno može predvideti afantazija; 3) Na osnovu preferencije žanra Triler/ Misterija se statistički značajno može predvideti afantazija; 4) Na osnovu preferencije žanra Sci-Fi/Fantastika se statistički značajno može predvideti afantazija; 5) Na osnovu preferencije žanra Horor se statistički značajno može predvideti afantazija; 6) Na osnovu preferencije žanra Drama se statistički značajno može predvideti afantazija; 7) Afantazija je statistički značajan prediktor preferencija određenih filmskih žanrova; 8) Postoje statistički značajne razlike između ispitanika koji preferiraju različite žanrove u pogledu afantazije.

Cilj ovog istraživanja bio je da se ispita da li se na osnovu preferencije filmskog žanra može predvideti nivo sposobnosti zamišljanja mentalnih slika ispitanika, te da se ispita postoje li statistički značajne razlike između ispitanika koji preferiraju različite filmske žanrove u pogledu afantazije.

\section{Metod}

\section{Uzorak}

Vrsta uzorka koji je korišćen u ovom istraživanju je prigodni. Vršeno je uzorkovanje bez vraćanja. Uzorak je sačinjavalo 953 ispitanika. Ispitivanje nije imalo starosno, obrazovno niti polno ograničenje. Od ukupnog broja ispitanika, muškarci su činili $20.6 \%(N=196)$, a žene $79.4 \%(N=757)$. Što se tiče starosne strukture ispitanika, najmlađi ispitanik ima 13 godina, dok najstariji ima 85 godina $(M=30.69$, $S D=11.05)$. S obzirom na to da su u istraživanju učestvovali maloletni ispitanici, a usled načina prikupljanja podataka nije bilo moguće prikupiti saglasnosti roditelja/ staratelja za učešće u istraživanju, njihovi odgovori su isključeni prilikom statističke obrade podataka. Nakon isključenja svih maloletnih ispitanika iz uzorka $(M=31.13$, $S D=10.93)$, uzorak je sačinjavalo 925 ispitanika, od toga $20.2 \%$ muškaraca $(N=$ 187) i 79.8\% žena $(N=738)$. U statističku obradu su uključeni svi ostali ispitanici, odnosno i ispitanici kod kojih je utvrđen skor koji odgovara afantaziji, kao i oni kod kojih je utvrđena visoka sposobnost zamišljanja mentalnih slika sa ciljem utvrđivanja eventualnih razlika u preferiranju određenih filmskih žanrova među njima, odnosno da li postoje pravilne razlike u biranju različitih filmskih žanrova među ispitanicima različito raspoređenih na kontinuumu sposobnosti zamišljanja mentalnih slika.

\section{Instrumenti}

Afantazija je operaciolizovana preko skora na instrumentu VVIQ (Vividness of Visual Imagery Questionnaire) koji je konstruisao britanski psiholog D. Marks (1973a). Skala se sastoji od 16 ajtema (s obzirom na to da se isti ajtemi postavljaju dva puta - jednom se traži od ispitanika da zamišlja otvorenih, a drugi put da zamišlja zatvorenih očiju) koji su podeljeni u četiri grupe po četiri ajtema. Ispitanici daju svoje odgovore na petostepnoj skali likertovog tipa (Savršeno jasna i živa, kao realno posmatrana $=$ ocena 1 , jasna $i$ donekle živopisna $=$ ocena 2 , umereno jasna $i$ 
živopisna = ocena 3, nejasna i mutna = ocena 4, nema slike uopšte, samo "znate" da razmišljate o nekom predmetu = ocena 5). Skala ima dve subskale - otvorene i zatvorene oči. Ukupan skor dobija se sabiranjem odgovora na svim stavkama ( $\min =32$, $\max =160)$. Za potrebe ovog upitnika fenomen afantazija je tretiran kao dimenzija, tj. minimalni skor $(\min =32)$ ukazuje na potpuno odsustvo afantazije, dok maksimalni skor $(\max =160)$ predstavlja izraženo prisustvo afantazije. Osobe koje su na ovom upitniku ostvarile minimalni skor $(\min =32)$ karakteriše zamišljanje savršeno jasnih i živih slika, kao da je realno posmatraju. Osobe koje su ostvarile maksimalni skor $(\max =160)$ karakteriše da u njihovom umu prilikom zamišljanja nema slike već postoji samo svest da se razmišlja o nečemu. VVIQ se oslanja isključivo na lično mišljenje ispitanika o tome šta vidi u svom umu. Ispitana pouzdanost dobijenih mera na VVIQ, i rezultati su pokazali zadovoljavajuću pouzdanost i kada je afantazija ispitivana metodom otvorenih $(\alpha=.874)$ i metodom zatvorenih očiju $(\alpha=.936)$.

Instrument za merenje preferencija filmskih žanrova - Ispitanicima je ponuđena lista filmova, prethodno sastavljena od mešavine od po 5 filmova svakog žanra koji je uključen u istraživanje (lista od po 5 filmova je preuzeta sa liste najbolje ocenjenih filmova iz svakog žanra na sajtu www.imdb.com). Zadatak ispitanika je bio da na toj listi obeleže svoje omiljene filmove ili, ukoliko nisu gledali nijedan od ponuđenih, odaberu one koje bi najradije pogledali. Ovaj instrument su konstruisali autori samo za potrebe ovog istraživanja. Prilikom instrukcije, ispitanicima je rečeno da sa ove liste odaberu svoje omiljene filmove; ukoliko nijedan od ponuđenih filmova nisu odgledali, da na listi obeleže one za koje su čuli i voleli bi da ih odgledaju, i ukoliko im nijedan od ponuđenih filmova nije poznat, polje ostave prazno.

Ispitanicima je bilo zadato i jedno pitanje zatvorenog tipa, da sa liste od 6 ponuđenih žanrova odaberu svoj omiljeni žanr (Akcija, Komedija, Triler/Misterija, Sci-Fi/Fantastika, Horor, Drama). Ovaj instrument su konstruisali autori samo za potrebe ovog istraživanja.

\section{Postupak ispitivanja}

Istraživanje se, s obzirom na trenutnu opasnost od zaraze Korona virusom, vršilo putem interneta, preko GoogleDocs platforme. Prikupljanje podataka trajalo je oko 5 dana, i za popunjavanje upitnika bilo je potrebno oko 10 minuta. Kako je istraživanje najviše sprovođeno putem Fejsbuk grupa čija je tematika vezana za filmove i umetnost, nije bilo većih problema prilikom prikupljanja podataka, štaviše većini ispitanika je predmet istraživanja bio jako zanimljiv. Mnogi ispitanici su bili motivisani činjenicom da im je obećano da će biti obavešteni o rezultatima istraživanja. 


\section{Rezultati}

Tabela 1

Preferencije žanrova

\begin{tabular}{ll}
\hline Žanrovi & $\boldsymbol{N}$ \\
\hline Akcija & 48 \\
Komedija & 153 \\
Triler/Misterija & 360 \\
Sci-Fi/Fantastika & 112 \\
Horor & 31 \\
Drama & 249 \\
\hline
\end{tabular}

Na početku ćemo prikazati deskriptivnu statistiku, odnosno koliko ljudi je koji žanr označilo kao omiljen; pitanje navedeno pod 3. stavku u sekciji Instrumenti (Tabela 1).

Što se tiče skorova na Afantaziji, dobijene su slične vrednosti u prosečnim vrednostima sposobnosti zamišljanja mentalnih slika na subskalama otvorenih $(M$ $=31.51 ; S D=10.20)$ i zatvorenih očiju $(M=32.32 ; S D=13.30)$. Ukupan prosečni skor na skali merenja sposobnosti zamišljanja mentalnih slika iznosi $M=63.83, S D$ $=21.26$. Na uzorku korišćenom u ovom istraživanju kod 23 ljudi je dobijeno potpuno odsustvo afantazije = mogućnost zamišljanja vrlo jasnih i živih slika (VVIQ skor jednak minimumu $=32$ ), odnosno $2.4 \%$ uzorka; dok je izraženo prisustvo afantazije - potpuna nemogućnost zamišljanja u slikama (VVIQ skor jednak maksimumu = 160) dobijeno kod 3 ispitanika, odnosno $0.3 \%$ uzorka.

Tabela 2

ANOVA - razlike između ispitanika koji preferiraju različite filmske žanrove u izraženosti ukupnog skora na afantaziji (ukupan skor i subskale)

\begin{tabular}{lccc}
\hline & $d f$ & $F$ & $p$ \\
\hline Afantazija & $5 / 919$ & 0.16 & .976 \\
Afantazija - otvorene oči & $5 / 919$ & 0.33 & .898 \\
Afantazija-zatvorene oči & $5 / 919$ & 0.67 & .646 \\
\hline
\end{tabular}

Napomena. $d f=$ stepeni slobode; $p=$ statistička značajnost.

Nakon ovoga, ispitavano je da li postoje statistički značajne razlike između ispitanika koji preferiraju različite žanrove u pogledu afantazije. Za to je korišćen postupak analize varijanse (ANOVA). Najpre je proveravano da li postoje razlike između ispitanika koji preferiraju različite filmske žanrove i ukupnog skora na afantaziji. Dobijeni rezultati nisu bili statistički značajni.

Nakon toga, ispitano je da li postoje statistički značajne razlike između ispitanika koji preferiraju različite filmske žanrove i skora na skali afantazija - otvorene oči, a zatim skora na skali afantazija - zatvorene oči (Tabela 2), ali ni tada nisu dobijeni statistički značajni rezultati. 
Tabela 3

Dvofaktorska analiza varijanse - povezanost varijabli pol $i$ žanr sa afantazijom

\begin{tabular}{lccc}
\hline & $F$ & $p$ & $\eta^{2}$ \\
\hline Pol & 13.75 & .000 & .015 \\
Omiljeni žanr & 1.23 & .293 & .007 \\
Pol*Omiljeni žanr & 1.20 & .305 & .007 \\
\hline
\end{tabular}

Napomena. Zavisna varijabla: Afantazija; pol: Muškarci $=1$; Žene $=2$.

Na kraju je provereno da li postoje statistički značajne razlike između ispitanika koji preferiraju različite filmske žanrove i ukupnog skora na afantaziji na poduzorku muškaraca i žena. Ovo je ispitivano postupkom dvofaktorske analize varijanse. Levenov test jednakosti varijacija bio je statistički značajan $(p=.010)$. Rezultati pokazuju da se statistički značajne razlike na nivou sposobnosti zamišljanja mentalnih slika dobijaju samo u odnosu na pol i time se objašnjava $1,5 \%$ varijanse na afantaziji $(F(1,913)=13.75, p=.000)$, dok ne postoji statistički značajna razlika na skoru afantazije kod ljudi koji biraju različite filmske žanrove $(F(5,913)=1.23$, $p=.293)$, kao i da interakcija pola i preferencije filmskih žanrova ne daje statistički značajne razlike $(F(5,913)=1.20, p=.305$; Tabela 3$)$.

Nakon ovoga, pristupljeno je ispitivanju da li se na osnovu preferencije žanra može statistički značajno predvideti nivo sposobnosti zamišljanja mentalnih slika ispitanika. Za ovo ispitivanje korišćen je postupak multiple linarne regresije. Pre prikaza rezultata linearane regresije, biće prikazana tabela interkorelacija kriterijuma i svih prediktora korišćenih kasnije u analizi regresije.

Tabela 4

Interkorelacije preferencija filmskih žanrova

\begin{tabular}{|c|c|c|c|c|c|c|c|}
\hline & 1. & 2. & 3. & 4. & 5. & 6. & 7. \\
\hline 1. Afantazija & 1 & & & & & & \\
\hline 2. Akcija & -.02 & 1 & & & & & \\
\hline 3. Komedija & -.06 & $-.07 *$ & 1 & & & & \\
\hline 4. Triler/Misterija & -.04 & $.32 * *$ & $.08^{*}$ & 1 & & & \\
\hline 5. Sci-Fi/Fantastika & -.00 & $.31 * *$ & -.01 & $.21 * *$ & 1 & & \\
\hline 6. Horor & -.01 & $.12 * *$ & -.05 & .05 & $.08^{*}$ & 1 & \\
\hline 7. Drama & -.05 & $.26 * *$ & $.22 * *$ & $.40 * *$ & $.20 * *$ & $.08 *$ & 1 \\
\hline
\end{tabular}

Napomena. *Statistička značajnost $<0.05, * *$ Statistička značajnost $<0.01$

U Tabeli 4 prikazane su vrednosti Pirsonovog koeficijenta korelacije. Iz tabele se vidi da, iako postoje statistički značajne korelacije među varijablama koje su kasnije korišćene kao prediktori, nijedna od njih nije visokog intenziteta. 
Tabela 5

Rezultati regresione analize - predviđanje ukupnog nivoa sposobnosti zamišljanja mentalnih slika na osnovu preferencija žanrova

\begin{tabular}{lcc}
\hline & $\beta$ & $p$ \\
\hline Akcija & -.01 & .790 \\
Komedija & -.06 & .104 \\
Triler/Misterija & -.03 & .430 \\
Sci-Fi/Fantastika & .01 & .779 \\
Horor & -.01 & .874 \\
Drama & -.02 & .558 \\
Model (set prediktora) & \multicolumn{2}{c}{$R^{2}=.006 ; p=.489$} \\
\hline
\end{tabular}

Napomena. $\beta=$ standardizovani regresioni koefinicient; $R^{2}=$ koef. determinacije.

Korišćeno je 6 prediktora, odnosno 6 filmskih žanrova koji su formirani tako što je analizirano koliko filmova određenog žanra je svaki ispitanik obeležio kao onaj koji najradije gleda (akcija, komedija, triler/misterija, sci-fi/fantastika, horor, drama). Rezultati pokazuju da model $(F(6,918)=0.91, p=.489)$ sa $R^{2}=.006$ nije statistički značajan (Tabela 5).

Tabela 6

Rezultati regresione analize (otvorene oči) - predviđanje nivoa sposobnosti zamišljanja mentalnih slika sa otvorenim očima na osnovu preferencija žanrova

\begin{tabular}{lcl}
\hline & $\beta$ & $p$ \\
\hline Akcija & -.00 & .947 \\
Komedija & -.09 & .010 \\
Triler/Misterija & -.07 & .081 \\
Sci-Fi/Fantastika & .02 & .499 \\
Horor & .02 & .477 \\
Drama & .01 & .830 \\
Model(set prediktora) & $R^{2}=.013 ; p=.064$ & \\
\hline
\end{tabular}

Napomena. $\beta=$ standardizovani regresioni koefinicient; $R^{2}=$ koef. determinacije.

Proveravano je i da li se na osnovu preferencije žanra može statistički značajno predvideti nivo sposobnosti zamišljanja mentalnih slika kod ispitanika na skali otvorenih očiju (Tabela 6). Statistički značajno predviđanje dobijeno je na skali otvorenih očiju na prediktoru Komedija, mada je dobijeno da model u celini $(F(6,918)=2.00$, $p=.064)$ sa $R^{2}=.013$ nije statistički značajan. 
Tabela 7

Rezultati regresione analize (zatvorene oči) - predviđanje nivoa sposobnosti zamišljanja mentalnih slika sa zatvorenim očima na osnovu preferencija žanrova

\begin{tabular}{lll}
\hline & $\beta$ & $p$ \\
\hline Akcija & -.01 & .708 \\
Komedija & -.02 & .532 \\
Triler/Misterija & .00 & .943 \\
Sci-Fi/Fantastika & -.00 & .946 \\
Horor & -.03 & .426 \\
Drama & -.04 & .271 \\
Model(set prediktora) & $R^{2}=.004 ; p=.742$ & \\
\hline
\end{tabular}

Napomena. $\beta=$ standardizovani regresioni koefinicient; $R^{2}=$ koef. determinacije.

Proveravano je i da li se na osnovu preferencije žanra može statistički značajno predvideti nivo sposobnosti zamišljanja mentalnih slika kod ispitanika na skali zatvorenih očiju (Tabela 7). Rezultati na skali zatvorenih očiju $(F(6,918)=0.59, p$ $=.742)$ sa $R^{2}=.004$ nisu se pokazali kao statistički značajni.

Tabela 8

Rezultati regresione analize - predviđanje preferencije komedije kao žanra

\begin{tabular}{llc}
\hline & $\beta$ & $p$ \\
\hline Afantazija - otvorene oči & -.12 & .003 \\
Afantazija -zatvorene oči & .05 & .230 \\
Model(set prediktora) & \multicolumn{2}{c}{$R^{2}=.010 ; p=.010$} \\
\hline
\end{tabular}

Napomena. Kriterijumska varijabla: Komedija.

Nakon ovoga, proveravano je da li bi multipla regresiona analiza suprotnog smera dala statistički značajne rezultate. Ovog puta zavisne varijable bili su različiti filmski žanrovi, dok su prediktori bile skale sposobnosti zamišljanja mentalnih slika zasebno sa otvorenim i zatvorenim očima. Ponovo nije utvrđena statistički značajna veza za sve osim za žanr Komedija gde sposobnost zamišljanja mentalnih slika objašnjava $1 \%$ varijanse $(F(2,922)=4.67, \mathrm{p}=.010)$ sa $R^{2}=.010$ (Tabela 8 ). Dobijeni beta koeficijent na subskali otvorenih očiju je negativan, što znači da će ljudi koji imaju manji skor na VVIQ (veća sposobnost zamišljanja mentalnih slika otvorenih očiju), imati veće preferencije ka filmovima žanra Komedija. 


\section{Diskusija}

Rezultati koji su dobijeni, iako nisu statistički značajni, ipak predstavljaju pomak u istraživanju fenomena afantazije, $\mathrm{s}$ obzirom na to da ne postoji veliki broj naučnih radova koji se bavio ovim fenomenom, a do sada se nijedno istraživanje nije bavilo povezanošću fenomena afantazije i filmskih žanrova. Rezultati ovog istraživanja nisu potvrdili nijednu od postavljenih hipoteza. Jedina hipoteza koja je delimično potvrđena je da se na osnovu skora na sposobnosti zamišljanja mentalnih slika statistički značajno može predvideti preferencija ka filmskom žanru Komedija, zato što su statistički značajni rezultati dobijeni samo za žanr Komedija na subskali otvorenih očiju. Kako je za žanr Komedija dobijen negativan beta koeficijent, zaključuje se da su skorovi na VVIQ instrumentu i na preferenciji određenih filmova obrnuto srazmerni, tj. osoba koja bira više filmova žanra komedija imaće manji skor na VVIQ, odnosno imaće veću sposobnost zamišljanja mentalnih slika. Ovo se eventualno može objasniti time što se ljudi koji imaju veću sposobnost zamišljanja mentalnih slika pre odlučuju za gledanje filmskog žanra koji oslikava realnu životnu situaciju sa primesama humora (Gilić, 2007), jer zamišljaju nešto što su, vrlo verovatno, već imali priliku da vide u realnom životu. Još jedno objašnjenje statistički značajnih rezultata samo na žanru Komedija moglo bi se pronaći i u izboru filmova koji su bili predstavnici ovog žanra jer su ispitanici koji su sačinjavali uzorak potencijalno imali veće sklonosti ka filmovima koji su bili ponuđeni.

Da bi se odnos između filmske umetnosti i fenomena afantazije dodatno ispitao, istraživanje bi se moglo sprovesti sa većom diferencijacijom filmskih žanrova, tako da u istraživanju umesto pet korišćenih filmskih žanrova, budu korišćeni svi filmski žanrovi do sada detektovani, kao i da filmovi predstavnici svakog žanra budu brojniji i prilagođeniji uzorku na kome se istraživanje vrši tako što bi se pre zadavanja glavnog upitnika, uradilo istraživanje opštih filmskih preferencija na datom uzorku i tako formirao adekvatniji instrument za ispitivanje preferencija filmskih žanrova. Ukoliko se u budućnosti bude primenila ova sugestija, mora se voditi računa o eventualnoj pojavi multikolinearnosti.

Provereno je, takođe, da li se rezultati dobijeni postupkom linearne regresije koji nisu statistički značajni mogu objasniti pojavom multikolinearnosti, međutim, utvrđeno je da ovo ipak nije slučaj s obzirom da između prediktora ne postoji statistički značajna visoka korelacija.

Kako su na subskalama afantazije - otvorene i zatvorene oči dobijene slične prosečne vrednosti, može se izvesti zaključak da ljudi približno istovetno zamišljaju i sa otvorenim i sa zatvorenim očima. Ova podela na zamišljanje otvorenih i zatvorenih očiju služi tome da se uporedi način zamišljanja, i ne ukazuje ni na kakve dodatne poremećaje ili fenomene. Zanimljiv je rezultat da se statistički značajno može predvideti preferencija ka žanru Komedija samo u situaciji kada ljudi zamišljaju otvorenim očima, što se ponovo može objasniti time da komedija oslikava realnu životnu situaciju sa primesama humora i odsustvom ozbiljnih životnih problema (Gilić, 2007), pre nego nešto potpuno apstraktno. Prosečne vrednosti, kako na 
subskalama zasebno, tako i na ukupnom skoru afantazije, na ovom uzorku se nalaze negde na sredini kontinuuma sposobnosti zamišljanja mentalnih slika.

Pored toga, vredno je pomenuti i to da je na uzorku korišćenom u ovom istraživanju dobijeno da je maksimalni skor na skali afantazije prisutan kod $0.3 \%$ ispitanika, što nije u skladu sa rezultatima prethodno rađenih istraživanja koja su pokazala da je afantazija prisutna kod 2-3\% opšte populacije (Kendle, 2017), s obzirom na to da je u ovom istraživanju izražena prisutnost afantazije pronađena kod manjeg broja ispitanika.

S obzirom na veličinu uzorka, dobijeni rezultati ne mogu se pripisati tome. Nije isključeno da bi drugačije strukturisan uzorak dao drugačije rezultate i eventualno potvrdio hipoteze ovog istraživanja. Ukoliko bi struktura uzorka bila takva da se on sastoji od ljudi koji se profesionalno bave filmom ili nekom drugom relevantnom oblašću umetnosti, možda bi rezultati potvrdili hipoteze ovog istraživanja.

Kako je afantazija slabo istraživan pojam, a da pri tome nikada nije istraživana povezanost afantazije sa bilo kojom oblasti umetnosti, u ovom odeljku nema mnogo prostora za upoređivanje rezultata dobijenih u ovom istraživanju sa rezultatima prethodno rađenih istraživanja.

Dobijeni rezultati mogu biti objašnjeni rezultatima prethodno rađenih istraživanja, koja govore o afantaziji kao urođenoj (Zeman et al., 2015) ili eventualno stečenoj (nakon nekih hirurških zahvata, različitih povreda ili psiholoških problema itd.; Zeman et al., 2010), dok su preferencije filmskih žanrova stečene i veoma podložne promenama kroz život. Iz tog razloga je primenjena multipla regresiona analiza, gde su kao prediktori korišćene skale afantazije zasebno sa otvorenim i zatvorenim očima. Tada je dobijeno da se afantazijom statistički značajno može predvideti samo varijansa žanra komedija, o čemu je ranije diskutovano.

Rezultati ovog istraživanja dovode do zaključka da se preferencijama filmskih žanrova ne može statistički značajno predvideti afantazija, kao ni da afantazija nije statistički značajan prediktor preferencija različitih filmskih žanrova na uzorku na kome je sprovedeno ovo istraživanje. Možda bi drugačije operacionalizovano istraživanje preferencija filmskih žanrova dovelo do drugačijih saznanja. S obzirom na to da hipoteze ovog istraživanja nisu potvrđene, smatramo da je ovo pomak ka rasvetljavanju odnosa fenomena afantazije sa drugim fenomenima, i da otvara puteve za nova istraživanja o afantaziji. Smatramo da je pomak $u$ istraživanjima ovog fenomena ostvaren, jer je pojam afantazije ispitivan u odnosu na nešto što do sada nikada nije, i eventualno buduća istraživanja ovog fenomena inspiriše na njegovo ispitivanje u odnosu na neke druge vrste umetnosti ili na drugačije operacionalizovano istraživanje u odnosu na filmsku umetnost.

\section{Zaključak}

Cilj ovog istraživanja bio je da se ispita da li se na osnovu preferencije filmskog žanra može predvideti nivo sposobnosti zamišljanja mentalnih slika ispitanika, 
te da se ispita postoje li statistički značajne razlike između ispitanika koji preferiraju različite filmske žanrove u pogledu afantazije.

Međutim, na kraju rada možemo da zaključimo da fenomen afantazije ne može da se predvidi na osnovu preferencija filmskih žanrova, kao i da ne postoje statistički značajne razlike u afantaziji između ispitanika koji preferiraju različite filmske žanrove. Metodom multiple linearne regresije suprotnog smera, dobijeno je da statistički značajno afantazija može da predvidi jedino preferencije žanra Komedija. Kako su postupkom multiple regresione analize suprotnog smera dobijeni različiti rezultati, na osnovu afantazije možemo do određene mere predvideti preferencije filmskih žanrova, što se eventualno može objasniti rezultatima prethodnih istraživanja koja su govorila o tome da je afantazija urođena (Zeman et al., 2015).

Teorijski značaj istraživanja bio bi da od rezultata dobijenih prilikom ovog istraživanja očekujemo da upotpune mali broj postojećih teorija afantazije.

Praktični značaj istraživanja bio bi da se buduća istraživanja afantazije usmere ka istraživanju povezanosti afantazije sa stabilnim osobinama ličnosti, temperamenta, kreativnosti. Pored toga, da se afantaziji više prilazi iz ugla neuronauka i neuropsihologije, s obzirom na to da sva dosadašnja istraživanja ukazuju na njenu neurološku osnovu.

Što se tiče nedostataka ovog istraživanja, prilikom konstrukcije upitnika za preferencije filmskih žanrova u istraživanju je mogao biti uključen veći broj filmskih žanrova, kao i širi izbor filmova kao predstavnika ponuđenih filmskih žanrova.

Preporuke za dalja istraživanja bile bi da se istraživači posvete istraživanju povezanosti afantazije sa stabilnim osobinama ličnosti, kao i upoređivanju afantazije na kliničkim i nekliničkim populacijama. Od stabilnih osobina ličnosti bilo bi dobro ispitati povezanost fenomena afantazije sa osobinom ekstraverzija-introverzija, kao i da se ispita da li postoji povezanost sa kreativnošću. Ukoliko bi neko istraživanje u budućnosti imalo za cilj dodatno ispitivanje povezanosti fenomena afantazija sa nekom od oblasti umetnosti, naša preporuka bi bila ispitivanje povezanosti afantazije i preferencija žanrova književnih dela, s obzirom na to da prilikom čitanja ljudi moraju da zamišljaju ono o čemu čitaju, dok filmovi ne ostavljaju puno prostora za zamišljanje, već gledaocima predstavljaju gotove slike. Bilo bi zanimljivo i ispitati afantaziju u odnosu na nivo obrazovanja i izbor karijere. Još jedna od preporuka bila bi da se pojam afantazije u budućnosti ispita na uzorcima različitih kultura, što bi nas moglo dovesti do nekih neverovatnih saznanja o afantaziji, ili potvrditi njenu urođenost.

\section{Reference}

Anderer, J. (2019, December 02). The Average Person Will Watch More Than 78,000 Hours Of TV [Web log post]. Retrieved from https://www.studyfinds.org/survey-theaverage-adult-will-watch-more-than-78000-hours-of-tv/

Aristotle. (1968). De anima. Books II and III (with certain passages from Book I) (Trans. D.W. Hamlyn). Oxford: Clarendon Press. 
Visualization. (n.d.). In Cambridge online dictionary. Retrieved from https://dictionary. cambridge.org/dictionary/english/visualization

Finke, R. A. (1986). Mental Imagery and the Visual System. Scientific American, 254(3), 88-95. https://doi.org/10.1038/scientificamerican0386-88

Galton, F. (1880). I. - Statistics of mental imaginary. Mind, os-V(19), 301-318. https://doi. org/10.1093/mind/os-v.19.301

Gilić, N.(2007): Filmske vrste i rodovi. Zagreb: AGM.

Gomery, D., \& Pafort-Overduin, C. (2011). Movie history: A survey. London: Routledge.

Hasler-Winter, S. (2018). An investigation into the relationship between visual imagery and stress. [Unpublished undergraduate project]. University of Manchester, Manchester, UK. https://doi.org/10.2224/sbp.2003.31.7.721

Hayward, S. (2006). Cinema Studies: The Key Concepts. London: Routledge.

Igartua, J. J.(2010). Identification with characters and narrative persuasion through fictional feature films. Communications, 35, 347-373. https://doi.org/10.1515/ comm.2010.019

Jacobs, C., \& Schwarzkopf, D. S., Silvanto, J. (2018). Visual working memory performance in aphantasia. Cortex, 105, 61 - 73. https://doi.org/10.1016/j.cortex.2017.10.014

Kendle, A. (2017). Aphantasia: experiences, perceptions, and insights. Oakamoor, Staffordshire: Dark River.

Keogh, R., \& Pearson, J. (2018). The blind mind: No sensory visual imagery in aphantasia, Cortex, 105, 53-60. https://doi.org/10.1016/j.cortex.2017.10.012

Kosslyn, S. M., Ganis, G., \& Thompson, W. L. (2001). Neural foundations of imagery. Nature Reviews Neuroscience, 2(9), 635 - 642. https://doi.org/10.1038/35090055

Marks, D. F. (1973a). Visual imagery differences in the recall of pictures. British Journal of Psychology, 64(1), 17 - 24. https://doi.org/10.1111/j.2044-8295.1973.tb01322.x

Marks, D. F. (1973b). Visual imagery differences and eye movements in the recall of pictures. Perception \& Psychophysics, 14(3), 407-412. https://doi.org/10.3758/ bf03211175

Warner, L., \& McNeill, M. E. (1988). Mental Imagery and Its Potential for Physical Therapy. Physical Therapy, 68(4), 516 - 521. https://doi.org/10.1093/ptj/68.4.516

Weaver, J. B., Brosius, H. B., \& Mundorf, N. (1993). Personality and movie preferences: A comparison of American and German audiences. Personality and Individual Differences, 14(2), 307 - 315. https://doi.org/10.1016/0191-8869(93)90128-p

Zeman, A. Z. J., Della Sala, S., Torrens, L. A., Gountouna, V.-E., McGonigle, D. J., \& Logie, R. H. (2010). Loss of imagery phenomenology with intact visuo-spatial task performance: A case of ,blind imagination.“ Neuropsychologia, 48(1), 145-155. https:// doi.org/10.1016/j.neuropsychologia.2009.08.024

Zeman, A., Dewar, M., \& Della Sala, S.(2015). Lives without imagery - congenital aphantasia. Cortex, 73, 378 - 380. https://doi.org/10.1016/j.cortex.2015.05.019 
Anja Stojković 3

Aleksandra Kostić

Monika Gluvačević

University of Niš,

Faculty of Philosophy

Niš, Serbia

\title{
THE CONNECTION BETWEEN THE PHENOMENON OF APHANTASIA AND THE PREFERENCE FOR THE CERTAIN MOVIE GENRES
}

\begin{abstract}
Aphantasia is a recently identified condition which is defined as the inability to create mental imagery. This study aimed to examine whether the level of mental imagery of respondents can be predicted based on the preference of the movie genre and to explore whether there are statistically significant differences between respondents who prefer different movie genres in terms of aphantasia. The sample consisted of 925 respondents $(M=187, F=738)$. Age range in the sample was from 18 to $85(M=31.13 ; S D=10.93)$. The aphantasia was operationalized through VVIQ (Vividness of Visual Imagery Questionnaire), the Instrument for Measuring Favorite Movie Genres, made for the purpose of this research was also used. Data processing was performed on the overall score of aphantasia, as well as on separate scales of open and closed eyes, and after that on a subsample of men and women, but the results were not statistically significant in any case. Both aphantasia scales of open $(\alpha=0.874)$ and closed eyes $(\alpha=0.936)$ show high internal consistency reliability. The results show that the phenomenon of aphantasia cannot be predicted based on the preferences of movie genres $(F(6,918)=0.91, p=.489$, $\left.R^{2}=.006\right)$, as well as that there are no statistically significant differences in aphantasia between respondents who prefer different film genres $(F(5 / 919)=0.16, p=.976)$. By the method of multiple linear regression of the opposite direction, we obtained that aphantasia can statistically significantly predict only the preferences of the Comedy genre $\left(F(2,922)=4.67, p=.010 ; R^{2}=.010\right)$ with $\beta=-.12 ; p=.003$. Since different results are obtained in the reverse order, based on aphantasia we can predict preferences for movie genres to a certain extent, which could speak in favor of previously done researches that claimed aphantasia is congenital.
\end{abstract}

Keywords: aphantasia - open eyes; aphantasia - closed eyes; movie genres; VVIQ; mental imagery

Primljeno: 30.06 .2020 .

Primljena korekcija: 13.09.2020.

Prihvaćeno za objavljivanje:14.09.2020.

\footnotetext{
${ }^{3}$ anjaa.stojkovic@gmail.com
} 